\title{
Psikolojik Güçlendirme İle Örgütsel Vatandaşlık Davranışının İlişkisi ve Demografik Değiş̧enlere Göre Farklılıkları: İzmir Şehir Merkezindeki Konaklama İşletmelerinde Bir Araştırma*
}

\section{The Relationship between Psychological Empowerment and Organizational Citizenship Behavior and Differences from Demographical Variables: A Research in Hospitality Enterprises of Izmir Metropolitan Area}

\section{Fatih ÇAVUŞOĞLU}

Balıkesir Üniversitesi

Sosyal Bilimler Enstitüsü

E-posta: fatihcavusoglu@hotmail.com.tr Orcid Id:0000-0003-4522-6401
Doç. Dr. Mehmet Emre GÜLER İzmir Kâtip Çelebi Üniversitesi

Turizm Fakültesi

E-posta: memre.guler@ikc.edu.tr Orcid Id:0000-0002-8689-9859

\section{Öz}

$\mathrm{Bu}$ araştırmanın temel amacı, konaklama işletmelerinde psikolojik güçlendirmenin örgütsel vatandaşlık davranışı üzerindeki etkisini ve demografik değişkenlere göre farklılık durumlarını tespit etmektir. Bu etkiyi ve farklılıkları test edebilmek için İzmir il merkezindeki beş yıldızlı konaklama işletmelerinde görev yapan 434 çalışana ulaşılarak anket uygulanmıştır. Katılımcıların anket formunda yer alan ifadelere katııım derecelerini belirlemek için frekans analizi, değişkenler arasındaki ilişkiyi belirlemek için korelasyon analizi, farklılıkları belirlemek için ANOVA ve t-testi uygulanmıştır. Yapılan analizler sonucunda, kendisini güçlendirilmiş hisseden personelin, örgütsel vatandaşlık davranışı sergileme eğiliminin daha yüksek düzeyde olduğu tespit edilmiştir.

Anahtar Kelimeler: Psikolojik güçlendirme, örgütsel vatandaşlık davranışı, turizm, konaklama işletmeleri, İzmir.

\begin{abstract}
The main purpose of this research is to determine effects of psychological empowerment on organizational citizenship behavior and differences according to the demographical factors in hospitality enterprises. In order to test these effects and differences, a survey has been applied to 434 employees of five-star hotels in Izmır Metropolitan Area. The frequency analysis for determining the degree of approval to the statements in questionnaire, correlation analysis for defining the relationships between variables and ANOVA and t-test for detecting the differences between variables have been applied. The results of analysis demonstrate that the employees who feel themselves empowered psychologically have tended to demonstrate higher level of organizational citizenship behavior.
\end{abstract}

Keywords: Psychological empowerment, organizational citizenship behavior, tourism, hospitality enterprises, İzmir.

*Bu çalışma, İzmir Kâtip Çelebi Üniversitesi Sosyal Bilimler Enstitüsü’nde hazırlanan "Psikolojik Güçlendirmenin Örgütsel Vatandaşlık Davranışı Üzerindeki Etkisi: İzmir İı Merkezindeki Beş Yıldızlı Konaklama İşletmelerinde Bir Araştırma" başlıklı yüksek lisans tezinden türetilmiştir. 


\section{Giriş}

Günümüzde, teknolojinin hızla gelişmesi, küreselleşme hareketinin yüksek bir hızla artması, müşteri talep ve intiyaçlarına hızlı ve etkin bir şekilde cevap verebilme zorunluluğunun artması nedeniyle iş görenlerin nitelikli olması gerekliliği önem kazanmıştır. İşletmelerin hedeflerine ulaşabilmesi, rekabet avantajını sağlayabilmesi, kaliteli hizmet ve ürün sunabilmesi için özellikle hizmet sektörü içerisinde insan unsurunun çok daha önemli bir konuma geldiği görülmektedir. "Emek yoğun" bir özelliğe sahip olan hizmet sektörünün alt dallarından biri olan turizm işletmelerinde de "önce insan" anlayışının ön plana çıktığı görülmektedir (Demir, 2004a: 293). Özellikle konaklama işletmelerinde hizmeti üreten ve sunan temel öğe insandır. Bu sebeple konaklama işletmelerinde başarının ve yüksek verimliliğin sağlanması, en üst düzeydeki yöneticiden en alt düzeydeki çalışana kadar tüm personelin bireysel çabalarına bağlı bulunmaktadır (Halis, 2009: 41).

Turizm faaliyetlerine katılanların durumuna göre turizm, yerel ve uluslararası olmak üzere ikiye ayrılmaktadır (Demir, 2004b: 325). Konaklama işletmeleri bu alanlarda nüfuz edeceği pazarda rekabet üstünlüğünü yakalayabilmek, müşteri tatmini ve tekrarlı müşteri akışını sağlayabilmek, değişimlere uyum sağlayabilmek ve insan kaynakları yönetimi anlayışı doğrultusunda hedeflerine ulaşabilmek için insan faktörüne önem vermek durumundadır. Bunun için, işletmeler, çalışanlarını eğitmeye ve geliştirmeye, yetki ve sorumluluk vermeye, yönetim ve kararlara katılımlarını sağlamaya, öncelik alma anlamında teşvik etmeye ilişkin uygulamalar geliştirmektedirler. Bu doğrultuda personelin yerine getirdiği faaliyetlerde kendisini değerli hissetmesini, yaptığı faaliyetleri sahiplenip kendi işi gibi görmesini ve psikolojik olarak güçlenmelerini amaçlamaktadırlar (Giderler, 2015: 62).

Konaklama işletmelerinin personelini güçlendirmeyi başarabilmesi, personelinin yaptığı işi gönüllü bir şekilde ve herhangi bir karşılık beklemeksizin yerine getirmesini, fazladan rol davranışları sergilemesini, örgüte bağlılı̆ının oluşmasını, çalışma arkadaşlarına ve yöneticilerine güven duymasını, yaptığı işten tatmin olmasını ve faaliyetleri yerine getirirken yüksek bir motivasyon ile çaba sarf etmesini beraberinde getirecektir. Örgütsel vatandaşlık davranışının temelinde yer alan bu tarz davranışların örgüt içerisinde görülmesi, konaklama işletmelerinin hedeflerine ulaşabilmesi açısından oldukça büyük önem arz etmektedir. Konaklama işletmelerinde insan kaynakları yönetimi politikalarının güçlendirme anlayışı üzerine kurulması, personelin örgütsel vatandaşlık davranışı gösterme eğilimine katkı sağlayacaktır.

Bu araştırmanın temel amacı İzmir il merkezinde yer alan beş yıldızlı konaklama işletmelerinde görev yapan personelin psikolojik güçlendirilme algısı ile örgütsel vatandaşlık sergileme eğilimi arasında bir ilişki olup olmadığını ve demografik faktörlere göre bir farklılık gösterip göstermediğini ortaya koymaktır. Aynı zamanda ilgili alan yazın incelendiğinde "personel güçlendirme" ve "psikolojik güçlendirme" kavramlarının birbirlerinin yerine sıklıkla kullanıldığı görülmektedir. Bu araştırma ile bu iki kavramın özünde aynı kavramlar olmadığını ve birbirlerinin yerine kullanılmaması gerektiğine işaret ederek ilgili yazına ve sektöre katkı sağlanması amaçlanmaktadır.

$\mathrm{Bu}$ araştırma, personelin kendisini güçlendirilmiş hissettiği algısına dayanan psikolojik güçlendirme ve psikolojik güçlendirmenin alt boyutlarını oluşturan anlamlılık, yeterlilik, özerklik ve etki boyutları ve örgütsel vatandaşlık davranışı alt boyutları olan, özgecilik, vicdanlılık, nezaket, centilmenlik ve sivil erdem boyutları üzerinden gerçekleşmektedir. Araştırma üç bölümden oluşmaktadır. İlk bölümde psikolojik güçlendirme kavramı, ikinci bölümde ise örgütsel vatandaşlık kavramı ayrıntılı bir 
şekilde incelenmiş ve tartışılmıştır. Çalışmanın üçüncü bölümünde yapılan araştırmanın yöntemi ile ilgili genel bilgiler, dördüncü bölümünde araştırma verilerinin analizi sonucunda elde edilen bulgular ve son bölümde ise araştırma ile ilgili tartışmalar, sonuç ve önerilere yer verilmektedir.

\section{Alan Yazın Araştırması}

Çalışmanın bu kısmında psikolojik güçlendirme ve örgütsel vatandaşlık davranışı ile ilgili alan yazında yapılan çalışmalar ışığında açıklamalar yapılacaktır.

\subsection{Psikolojik Güçlendirme}

Psikolojik güçlendirme, Spreitzer'e göre (1995), “örgütteki güçlendirme müdahalelerinin başarılı olması için çalışanlar tarafından deneyimlenmesi gereken psikolojik bir durum olarak tanımlanmaktadır" (Sürgevil ve diğ., 2013: 5374). Güçlendirmenin özünde yapısal ve güdüsel olarak iki ayrı boyut bulunmaktadır. Güçlendirmenin yapısal yaklaşımında gücün, güçlü olandan daha az güçlü olan kişilere aktarılmasını sağlayan üst düzey yöneticilerin yaptıklarına odaklanılmakta, güçlendirilen kişilerin psikolojik durumu dikkate alınmamaktadır. Kişilerin psikolojik durumunun dikkate alınmaması, beraberinde güdüsel yaklaşımın ortaya çıkmasını getirmektedir. (Tolay ve diğ., 2012: 449). Spreitzer (1995) psikolojik temelde güçlendirmeyi temelde dört ana boyut altında toplamaktadır. $\mathrm{Bu}$ boyutları, anlamlılık, yeterlilik, özerklik ve etki olarak adlandırmaktadır (Spreitzer, 1995: 1443).

- Anlamlılık boyutu, bireyin kendi idealleri, hedefleri ve standartları ile bağlı bulunduğu örgütün hedef ve değerleri arasındaki ilişkinin uyumlu olmasını ifade etmektedir. Bu değerler tamamen personelin sahip olduğu idealler ve standartlara bağlı olarak, personel tarafından belirlenmektedir. Yürütülen işin gerekleri ile personelin inançları değerleri ve davranışları arasındaki uyum arttıkça, işin kişi için taşıdığı anlam da artmaktadır (Lee ve Koh, 2001: 686; Çöl, 2008: 37).

- Yeterlilik boyutu, bir kişinin iş faaliyetlerini başarı ile gerçekleştirebilme derecesini ifade etmektedir (Thomas ve Velthouse, 1990: 672). Başka bir ifadeyle kişinin kendisini işi konusunda yeterli hissetmesi, performans ve yeteneklerine güvenmesi anlamına gelmektedir (Spreitzer ve diğ., 1997: 682).

- Özerklik boyutu, bireyin yapacağı iş sürecinin başlangıcında ve devamında kendi davranışlarını düzenleme ve bu davranışlara yön verme konusunda bir ölçüde bağımsız oluşunu ifade etmektedir. İşte atılacak adımların, sarf edilecek çabanın ve kullanılacak yöntemlerin belirlenmesinde, personelin üst yönetimden bağımsız bir şekilde karar alabilme özgürlüğüdür (Spreitzer ve diğ., 1999: 512).

- Etki boyutu, personelin örgüt içerisinde stratejik, yönetsel ya da operasyonel sonuçlar üzerinde bıraktığı bir etki olup olmadığı algısını ifade etmektedir (Tolay ve diğ., 2012: 452).

Arı'nın (2014) örgütlerdeki fiziksel semboller ve psikolojik güçlendirme ilişkisi üzerine yaptığı kavramsal bir çalışmada, örgüt içerisinde statü ve kimlikleri etkileyen giysiler, aksesuarlar, binalar, teknoloji gibi fiziksel sembollerin personelin kendisini güçlendirilmiş hissetmesine olumlu anlamda etki ettiğini ortaya koymuştur. Çalışkan ve Hazır (2012) elektronik haberleşme sektöründe yer alan özel işletmeler üzerinde psikolojik güçlendirmenin iş tatmini üzerindeki etkisi ve örgütsel bağlılığı sağlamadaki aracılık rolü üzerinde bir çalışma gerçekleştirmiş ve psikolojik güçlendirmenin hem iş 
tatmini hem de örgütsel bağlılığın oluşturulmasında önemli bir rolü olduğu sonucuna ulaşmışlardır. Tolay ve diğ. (2012) akademik çalışma ortamında bulunan kişilerin güçlendirilme algısının duygusal bağlılık ve iş doyumu üzerindeki etkilerini ortaya koymaya yönelik yaptıkları çalışmada, psikolojik güçlendirmenin iş doyumu ve duygusal bağlılık üzerinde doğrudan ve pozitif yönde bir etkisi olduğunu tespit etmişlerdir.

Bir işletmenin, çalışanlarına psikolojik güçlendirme yaklaşımı uygulamasındaki amaçlar, işini anlamlı ve önemli gören, sürekli öğrenmeye ve kendini geliştirmeye açık olan, bilgi seviyesi yüksek, işletmesine ve onun özelliklerine hakim, kendine güveni yüksek, kendini işi konusunda yeterli hisseden, görüş ve önerilerini rahatça ifade edebilen ve kararlara katılabilen, işletmesine ve bağlı bulunduğu departmana olumlu etkiler sağlayabilen ve belli bir amacı olan kişiler olmalarını sağlayabilmektir. Personeli psikolojik olarak güçlendirme yaklaşımının işletme içerisinde etkin bir şekilde uygulanması; personelin yaptığı işten tatmin olmasını, kendisini mutlu hissetmesini, bu olumlu hissiyatlarını işletmesine ve çalışma arkadaşlarına yansıtmasını sağlamaktadır. Bu sayede çalışanlar işletme içerisinde olumlu bir iklim oluşturulabilir, yöneticilerine ve çalışma arkadaşlarına güven duyması, bağlı bulunduğu bölüm içerisinde gönüllü bir şekilde yardımsever tutum sergilemesi, çalıştığı kurumu kendi işletmesi gibi görerek işlerini yerine getirmesi sağlanabilir.

\section{2. Örgütsel Vatandaşlık Davranışı}

Örgütsel vatandaşlık davranışı, personelin örgütle olan anlaşmasında net bir şekilde belirtilmemiş, örgütsel rolünün ya da iş tanımının gerektirmediği, bireysel seçime bağlı olan ve uygulamaya konulmadığında cezai bir yaptırım, uygulamaya konulduğunda ise ödül gerektirmeyen davranışlardır (Turnipseed, 2002: 2). Işe vaktinde gelme ve verilen görevleri yerine getirmenin dışında personelin, birbirleri ile görüşmelerine ve birlikte dayanışma içerisinde çalışmalarına, işletme içinde ve dışında yapılan suçlamalar karşısında örgütü savunmalarına, kaliteyi ve verimliliği oluşturabilmek için değişimi desteklemelerine ve uyum sağlayabilmelerine, iş ile ilgili bilgileri birbirleri ile paylaşmalarına ve huzurlu bir iş ortamı oluşturma konusunda çabalarına intiyaç duyulmaktadır. Kendilerine verilen görev ve faaliyetleri ve daha fazlasını karşıı beklemeksizin kendiliğinden yapan, huzurlu bir çalışma ortamı oluşturulması için çaba sarf eden, ait olduğu örgüte değer veren ve gönül bağı hisseden personelin davranışları örgütsel vatandaşlık davranışından başka bir şey değildir (Çelik, 2007: 82).

Örgütsel vatandaşlık boyutları üzerine yapılan çalışmaların en kabul göreni Organ'ın 1988 yılında yazına kazandırdığı "Organizational Citizenship Behaviour: The Good Soldier Syndrome" isimli çalışmasıdır. Organ, bu çalışmasında örgütsel vatandaşlık davranışını beş boyutta ele almıştır (Çelik, 2007: 126; Aslan, 2009: 261):

- İşle ilgili problemlerde diğer çalışma arkadaşlarına yardımda bulunmaya ilişkin davranışlar anlamına gelen "özgecilik",

- Görevde dakik olma, kaynakları koruma ve işe devamlılık gibi davranışları kapsayan "vicdanlılık",

- Çalışma arkadaşları için problemler doğmasının önüne geçmek amacıyla tedbirler alarak onlara yardımcı olmayı ve bilgilendirmeyi içeren davranışlar anlamına gelen "nezaket",

- Şikayet etmeden ve isteyerek işin zorluğunu kabul etme ve kolay uyum sağlayabilme anlamına gelen "centilmenlik", 
- Personelin örgütün politik yaşamına katılımını, bağlılı̆ını ve yüksek ilgisini gösteren faaliyetler bütünü olarak ifade edilen "sivil erdem" boyutlarıdır.

Yeşilyurt ve Koçak'ın (2014) konaklama işletmelerinde iş doyumu ve örgütsel vatandaşlık davranışı arasındaki ilişkiyi incelemek adına ortaya koydukları çalışmada, yüksek iş doyum düzeyi olan konaklama işletmeleri personelinin örgütsel vatandaşlık sergileme eğilimlerinin de yüksek düzeyde olduğu sonucuna ulaşmışlardır. Meydan ve arkadaşları (2011) adalet algısı ve tükenmişliğin örgütsel vatandaşlık davranışı üzerinde ne derecede etkili olduğunu ortaya koymayı amaçladıkları çalışmada, kendisini işi konusunda tükenmiş hisseden personelin, örgütsel vatandaşlık davranışı sergilemesini olumsuz anlamda etkilediğini tespit etmişlerdir. Aslan'ın (2008) örgütsel vatandaşlık davranışı ile örgütsel bağlılık ve mesleki bağlılık arasındaki ilişkiyi belirlemek adına yapmış olduğu çalışmada, mesleğine duygusal bağlılık besleyen bireylerin örgütsel vatandaşlık davranışı sergileme eğilimlerinin arttığını, buna karşın bireylerin örgüte bağlılık düzeyi ile örgütsel vatandaşlık sergileme eğilimi arasında herhangi bir ilişki olmadığını tespit etmiştir. Sökmen ve Boylu'nun (2011) konaklama işletmelerinde örgütsel vatandaşlık davranışı sergileme eğiliminin cinsiyete göre bir farklılık gösterip göstermediğine ilişkin yaptıkları çalışmada, örgütsel vatandaşlık davranışının her bir boyutu ile inceleyerek kadınların, yardımsever ve nezaket tabanlı çalışma arkadaşlarını bilgilendirme düzeylerinin erkeklere göre daha yüksek olduğunu; örgüt içerisinde çözüm odaklı olma, olayların pozitif yönünü görme, örgütüne yüksek bağlılık ve ilgi duyma yaklaşımlarının ise erkeklerde kadınlara oranlara daha fazla olduğunu tespit etmişlerdir. Gürbüz ve Yüksel'in (2008) duygusal zeka ile örgütsel vatandaşlık davranışı arasındaki ilişkiyi belirlemek için yaptıkları çalışmada, personelin çalışma ortamındaki duygusal zekası ile örgütsel vatandaşlık davranışı arasında anlamı bir ilişki olmadığı tespit edilmiştir.

Konaklama işletmelerinin vermiş olduğu hizmetlerde en önemli kıstasın müşteri memnuniyeti olduğu göz önüne alındığında örgütsel vatandaşlık davranışının önemi ortaya çıkmaktadır. İyi bir örgüt vatandaşı, yaptığı işten doyum sağlamakta, motivasyonu artmakta, bağlı bulunduğu örgüt ile bütünleşmekte, örgüt içinde etkinliği ve verimliliği artmaktadır. Örgütsel vatandaşlık davranışının, personel ve örgüt verimliliğini arttırması ile hizmet kalitesini de eş zamanlı arttırması doğal bir sonuç olacaktır. Örgütsel vatandaşlık davranışı sergileyen personele sahip konaklama işletmeleri, rakiplerine karşı hizmet anlamında fark yaratarak rekabet avantajı sağlayabileceklerdir. Aynı zamanda turizm sektöründe, işini severek ve motive olmuş bir şekilde yerine getiren, fazladan rol davranışı sergileyen, yaptığı işi kendi işi gibi gören ve yüksek kalitede hizmet vermeyi amaçlayan personele sahip olan turizm işletmeleri, ülke turizminin gelişimine büyük katkılar sağlayabileceklerdir (Keleş ve Pelit, 2009: 40).

\section{Araştırmanın Yöntemi}

Araştırma için intiyaç duyulan verileri toplama aracı olarak anket tekniğinden yararlanılmıştır. Anket tekniği hem anket formlarıyla hem de internet üzerinden oluşturulan çevrimiçi anket aracılığıyla katılımcılara ulaştırılmıştır. Araştırma için hazırlanan anketin güvenilirliği için söz konusu işletmelerde bulunan 50 çalışana ön test yapılmış, veriler SPSS istatiksel analiz programında analiz edilmiştir. Yapılan güvenilirlik analizinde Cronbach Alpha katsayısı psikolojik güçlendirme ölçeği için 0,926, örgütsel vatandaşlık davranışı ölçeği için 0,943 bulunmuştur. Bulunan bu değerlerin 1,00'e yakın bir değer olması sonucunda anketin güvenilirliğine ve araştırmada uygulanmasına karar verilmiştir. 
Anket formunun hazırlanması sürecinde, bu konu ile ilgili alanlarında uzman kişilerin görüş ve önerilerinden yararlanılarak, istatiksel analize uygunluğu hakkında istatistik uzmanı kişilerle görüşülerek ve ön test katılımcılarının anket formunda yer alan ifadelerle ilgili görüş ve eleştirileri alınarak anket formu geliştirilmiştir. Anket formu 5’li Likert ölçeğine göre hazırlanan toplam 38 sorudan ve 2 bölümden oluşmaktadır.

Anketin birinci bölümü, işletmede görev yapan personelin demografik özelliklerini ölçmek üzere tasarlanmıştır. Anketin ikinci bölümünde yer alan psikolojik güçlendirme algısının derecesini belirlemeye yönelik ifadeler, geçerliliği ve güvenilirliği araştırmacılar tarafından test edilmiş ve ülkemizde birçok araştırmada kullanılan (Çavuş, 2008; Çöl, 2008; Çekmecelioğlu ve Keleş, 2008; Çavuş ve Akgemici, 2008; Işın, 2009) Spreitzer'in geliştirdiği psikolojik güçlendirme ölçeği esas alınarak hazırlanmıştır. Örgütsel vatandaşlık davranışının derecesini belirlemeye yönelik ifadeler ise, Basım ve Şeşen (2006) tarafından geçerliliği ve güvenilirliği test edilmiş olan ve 19 ifadeden oluşan örgütsel vatandaşlık davranışı ölçeği kullanılmıştır. Basım ve Şeşen (2006: 92) tarafından iki ayrı çalışmadan faydalanılarak hazırlanan bu ölçek Vey ve Campbell (2004) ile Williams ve Shiaw (1999) tarafından geliştirilen ölçeklerden faydalanılarak hazırlanmış olup, Organ (1988) tarafından ortaya konulan ve araştırmacılar tarafından en fazla araştırılan beş temel örgütsel vatandaşlık davranışı boyutunu ölçebilmek üzere tasarlanmıştır.

\subsection{Araştırmanın Evren ve Örneklemi}

Araştırmanın evrenini İzmir il merkezinde yer alan toplam 6 adet beş yıldızlı konaklama işletmesi oluşturmaktadır. Bu konaklama işletmelerinde, ilgili işletmelerin insan kaynakları biriminden alınan personel sayısı olan 1175 kişi çalışmaktadır. Anket formları, konaklama işletmelerine bizzat gidilerek, işletmelerin yemekhane ve kafeteryalarında personelin mola vakitlerinde aynı zamanda personelin mesai çıkışlarında konaklama işletmesi personeline uygulanmıştır. İnternet ortamında hazırlanan anket ise, web sitesi aracılığıyla ilgili personele yollanmış ve konaklama işletmesi içerisinde görev yapan çalışma arkadaşlarına aynı bağlantı linkinin yollanarak uygulatılması istenmiştir. Tam sayımın yapılmak istendiği çalışmada toplam 550 kişiye ulaşılarak anket uygulanmıştır. Bunlardan 434 anketin analize uygun olduğu belirlenmiş ve ana kütlenin \%37'sine ulaşılmıştır ve çalışmada bu anketler kullanılmıştır. İzmir il merkezinde yer alan beş yıldızlı otellerin bu araştırma için seçilmesinin nedeni İzmir'de şehir otelciliğinin geçmişten günümüze değin gelişmiş olmasıdır. Ayrıca beş yıldızlı konaklama işletmelerinin ulusal ve uluslararası anlamda kurumsal bir yapıya sahip olmalarından dolayı akademik anlamda daha güvenilir verilere erişilebileceği düşünülmüştür. Bunun yanı sıra İzmir kent merkezinde yapılan bu çalışmayla katıımcılara daha hızlı ulaşılmış ve veri toplama maliyetleri bu sayede düşürülmüştür.

\subsection{Araştırmada Kullanılan İstatistiksel Yöntemler}

Araştırmada elde edilen veriler SPSS 22.0 yazılımı kullanılarak analiz edilmiştir. Anketin güvenilirliğini test etmek amacıyla Cronbach Alpha katsayısı değerinden faydalanılmıştır. Ankette yer alan ifadelere örneklem grubunun katılım düzeyleri frekans analizi yardımıyla analiz edilmiştir. Araştırmada kullanılan ölçeklerin ilgili alan yazında yer aldığı gibi aynı alt boyutlarda olup olmadığını test etmek için faktör analizi uygulanmıştır. Değişkenler arasındaki ilişkiyi incelemek için korelasyon analizinden, değişkenler arasındaki farklılığı incelemek için ise ANOVA analizi ve $t$ testinden yararlanılmıştır. 


\section{Bulgular}

Araştırmanın bu bölümünde; katılımcıların demografik özelliklerinin ve ankette yer alan ölçek sorularına verdikleri cevapların frekans analizleri, araştırmada kullanılan ölçeklerin güvenilirlik ve faktör analizi, değişkenler arasındaki ilişkiyi test edebilmek amacıyla yapılan korelasyon analizi, değişkenler arasındaki farklılığı incelemek amacıyla gerçekleştirilen $\mathrm{t}$ testi ve ANOVA analizleri ile ilgili tablolar ve yorumlamalara yer verilmektedir.

\subsection{Araştırmada Kullanılan Ölçeklere İlişkin Güvenilirlik Analizleri}

Güvenilirlik analizi, herhangi bir araştırmada örneklemi oluşturan birimler üzerinden veri toplamak amacıyla geliştirilen ölçek ifadelerinin kendi aralarında tutarlılık gösterip göstermediğini belirleyebilmek amacıyla kullanılmaktadır. Araştırmada güvenilirlik analizi için Cronbach Alpha katsayı değeri kullanılmıştır. Yapılan analiz sonucu elde edilen Cronbach Alpha $(\alpha)$ şu şekilde yorumlanmaktadır (Kalaycı, 2006: 45):

- $0,00 \leq \alpha \leq 0,40$ aralığında ise güvenilir değil,

- $0,40 \leq \alpha \leq 0,60$ aralığında ise güvenilirliği düşük,

- $0,60 \leq \alpha \leq 0,80$ aralığında ise oldukça güvenilir,

- $0,80 \leq \alpha \leq 1,00$ aralığında ise ölçek yüksek derecede güvenilir bir ölçektir.

Tablo 1 ve Tablo 2'de sunulduğu üzere, araştırmada kullanılan her iki ölçeğin de yüksek derecede güvenilir ölçekler olduğu görülmektedir.

Tablo 1: Psikolojik Güçlendirme Ölçeğine İlişkin Güvenilirlik Analizi

\begin{tabular}{|l|c|c|}
\hline & Cronbach $\boldsymbol{\alpha}$ Katsayısı & Değişken Sayısı \\
\hline Psikolojik Güçlendirme & 0,904 & 12 \\
\hline$\bullet \quad$ Anlamlılı & 0,917 & 3 \\
\hline$\bullet \quad$ Yeterlilik & 0,828 & 3 \\
\hline - Özerklik & 0,893 & 3 \\
\hline$\bullet \quad$ Etki & 0,896 & 3 \\
\hline
\end{tabular}

Tablo 2: Örgütsel Vatandaşlık Davranışı Ölçeğine İlişkin Güvenilirlik Analizi

\begin{tabular}{|l|c|c|}
\hline & Cronbach $\boldsymbol{\alpha}$ Katsayısı & Değişken Sayısı \\
\hline Örgütsel Vatandaşlık Davranışı & 0,929 & 19 \\
\hline$\bullet$ Özgecilik & 0,809 & 5 \\
\hline$\bullet$ Vicdanlılık & 0,697 & 3 \\
\hline$\bullet$ Nezaket & 0,845 & 3 \\
\hline$\bullet$ Centilmenlik & 0,756 & 4 \\
\hline$\bullet$ Sivil Erdem & 0,836 & 4 \\
\hline
\end{tabular}

Kullanılan ölçeklerin geçerli sayılabilmesi için bu ölçeklerin güvenilir olması bir koşuldur ancak sadece güvenilir olması da geçerli olduğu anlamı taşımayabilir. Araştırmada kullanılan psikolojik güçlendirme ölçeğinin geçerliliği ve güvenilirliği araştırmacılar tarafından test edilmiş ve birçok araştırmada kullanılmıştır (Arslantaş, 2007; Çavuş, 2008; Demir, 2010; Çöl, 2008; Çekmecelioğlu ve Keleş, 2008; Çavuş ve Akgemici, 2008; Işın, 2009). Örgütsel vatandaşlık davranışının ölçeği ise, Basım ve Şeşen (2006) tarafından geçerliliği ve güvenilirliği test edilmiş olan ölçek Vey ve Campbell (2004) ile Williams ve Shiaw (1999) tarafından geliştirilen ölçeklerden faydalanılarak hazırlanmıştır. Çalışmada geçerliliği sağlanmış ölçekler kullanılmıştır. 


\subsection{Frekans Analizleri}

Araştırmanın bu bölümünde, araştırmaya katılan bireylerin demografik özelliklerine ve araştırmada kullanılan ölçeklere ilişkin frekans analizi sonuçları yer almaktadır.

\subsubsection{Katılımcıların Demografik Özelliklerine İlişkin Frekans Analizleri}

Tablo 3: Katılımcıların Demografik Özellikleri

\begin{tabular}{|c|c|c|c|c|c|}
\hline Cinsiyet & Frekans (n) & Yüzde (\%) & Çalışılan Bölüm & Frekans (n) & Yüzde (\%) \\
\hline Erkek & 253 & 58,3 & Ön Büro & 57 & 13,1 \\
\hline Kadın & 181 & 41,7 & Kat Hizmetleri & 68 & 15,6 \\
\hline $\begin{array}{l}\text { Medeni } \\
\text { Durum }\end{array}$ & Frekans (n) & Yüzde (\%) & Yiyecek-İçecek & 147 & 33,9 \\
\hline Evli & 239 & 55,1 & Satış-Pazarlama & 44 & 10,1 \\
\hline Bekâr & 180 & 41,5 & Muhasebe & 24 & 5,5 \\
\hline Diğer & 15 & 3,4 & Misafir İlişkileri & 18 & 4,1 \\
\hline Eğitim & Frekans (n) & Yüzde (\%) & İnsan Kaynakları & 18 & 4,1 \\
\hline İlköğretim & 36 & 8,3 & Bilgi - İşlem & 9 & 2,2 \\
\hline Lise ve Dengi & 127 & 29,3 & Teknik Hizmetler & 43 & 10,0 \\
\hline Ön Lisans & 60 & 13,8 & Yönetim & 6 & 1,4 \\
\hline Lisans & 166 & 38,2 & $\begin{array}{c}\text { Turizmde Çalışma } \\
\text { Süresi }\end{array}$ & Frekans (n) & Yüzde (\%) \\
\hline $\begin{array}{l}\text { Yüksek } \\
\text { Lisans }\end{array}$ & 40 & 9,2 & 1 Yıldan Az & 44 & 10,1 \\
\hline Doktora & 5 & 1,2 & $1-5 Y_{I I}$ & 163 & 37,6 \\
\hline Yaş & Frekans (n) & Yüzde (\%) & 6-10 Yıl & 128 & 29,5 \\
\hline 18'den küçük & 9 & 2,1 & $11-15 Y_{I I}$ & 68 & 15,7 \\
\hline $18-24$ & 252 & 58,1 & $16-20 \mathrm{Yll}_{\mathrm{I}}$ & 20 & 4,6 \\
\hline $25-44$ & 133 & 30,6 & 21 Yıl ve Üzeri & 11 & 2,5 \\
\hline $45-59$ & 30 & 6,9 & $\begin{array}{c}\text { İşletmede Çalışma } \\
\text { Süresi }\end{array}$ & Frekans (n) & Yüzde (\%) \\
\hline \multirow[t]{6}{*}{60 ve üstü } & 10 & 2,3 & 1 Yıldan Az & 126 & 29 \\
\hline & & & $1-5 Y_{I I}$ & 225 & 51,8 \\
\hline & & & 6-10 YII & 62 & 14,3 \\
\hline & & & 11-15 Yll & 13 & 3,0 \\
\hline & & & $16-20 Y_{\mathrm{Il}}$ & 3 & 0,7 \\
\hline & & & 21 Yıl ve Üzeri & 5 & 1,2 \\
\hline
\end{tabular}

Tablo 3'te görüldüğü üzere katılımcıların çoğunluğunu $(\% 58,3)$ erkekler oluşturmaktadır. Tablo 3'te sunulduğu üzere katılımcıların çoğunluğunun $(\% 55,1)$ evli olduğu belirlenmiştir. Bunun yanı sıra katılımcıların büyük çoğunluğunun 18-24 yaş grubunda $(\% 58,1)$ yer aldığı görülmektedir. \% 40'ı oluşturan bir grup ise 25 yaş ve üstünü oluşturmaktadır. Eğitim durumuna göre katılımcıların büyük çoğunluğunun lisans düzeyinde $(\% 38,2)$ eğitime sahip olduğu görülmektedir. Araştırmaya katılan bireylerin büyük bölümünün $(\% 33,9)$ yiyecek-içecek departmanında görev yaptığı ve bu katılımcıların büyük bölümünün $1-5$ yıl arası $(\% 37,6)$ turizm sektöründe görev yaptığı görülmektedir. Çoğunluğun ise bulundukları işletmede yine 1-5 yıl arasında çalıştıklarına ilişkin analiz tabloda sunulmaktadır.

\subsubsection{Araştırmada Kullanılan Ölçeklere İlişkin Frekans Analizleri}

Araştırmanın bu bölümünde, araştırmada kullanılan psikolojik güçlendirme ve örgütsel vatandaşıı davranışı ölçeklerine, örneklem grubunun katılım düzeylerine ilişkin frekans analizlerine yer verilmektedir. Tablo 4 ve Tablo 5 'te sunulduğu üzere, katılımcıların psikolojik güçlendirme alt boyutlarında "anlamlılık" ve "yeterlilik" boyutlarına ve örgütsel vatandaşlık davranışı alt boyutlarından "özgecilik" ve "nezaket" 
alt boyutlarına diğer alt boyutlardan daha yüksek düzeyde bir katılım düzeyi gösterdikleri görülmektedir.

Tablo 4: Katılımcıların Psikolojik Güçlendirme Algısı Düzeyine İlişkin Frekans Analizi

\begin{tabular}{|c|l|c|c|}
\hline \multicolumn{1}{|c|}{ İfadeler } & $\begin{array}{c}\text { Aritmetik } \\
\text { Ortalama }\end{array}$ & $\begin{array}{c}\text { Standart } \\
\text { Sapma }\end{array}$ \\
\hline 1 & Yaptığım iş benim için önemlidir. & 4,40 &, 912 \\
\hline 2 & işimle ilgili yaptığım faaliyetler benim için özel bir anlam taşır. & 4,28 &, 934 \\
\hline 3 & Yaptığım iş benim için anlamlıdır. & 4,31 &, 898 \\
\hline 4 & Işsimi yapmak için gereken yeteneklere sahip olduğuma eminim. & 4,48 &, 751 \\
\hline 5 & Iş̧imi yapmak için gerekli kapasiteye sahibim. & 4,53 &, 716 \\
\hline 6 & Işsim için gereken becerilere uzmanlık seviyesinde sahibim. & 4,08 &, 940 \\
\hline 7 & Isşimi nasıl yapacağımı belirleme konusunda özgürüm. & 3,71 & 1,082 \\
\hline 8 & Işimi nası yürüteceğime dair kararları kendim verebiliyorum. & 3,72 & 1,079 \\
\hline 9 & Isşimi yaparken farklı yöntemleri seçme konusunda özgürüm. & 3,69 & 1,094 \\
\hline 10 & Departmanımda olanlar üzerinde büyük bir kontrole sahibim. & 3,49 & 1,224 \\
\hline 11 & Departmanımdaki faaliyetler üzerindeki etkim fazladır. & 3,66 & 1,124 \\
\hline 12 & Departmanımda olanlar üzerinde önemli bir etkiye sahibim. & 3,59 & 1,168 \\
\hline
\end{tabular}

Tablo 5: Katılımcıların Örgütsel Vatandaşlık Davranışı Sergileme Düzeyine İlişkin Frekans Analizi

\begin{tabular}{|c|c|c|c|}
\hline & İfadeler & $\begin{array}{l}\text { Aritmetik } \\
\text { Ortalama }\end{array}$ & $\begin{array}{l}\text { Standart } \\
\text { Sapma }\end{array}$ \\
\hline 1 & Günlük izin alan bir çalışanın o günkü işlerini ben yaparım. & 3,72 & 1,225 \\
\hline 2 & Aşırı iş yükü ile uğraşan bir çalışma arkadaşıma yardım ederim. & 4,36 & ,843 \\
\hline 3 & Yeni işe başlayan birisinin işi öğrenmesine yardımcı olurum. & 4,54 & ,753 \\
\hline 4 & $\begin{array}{l}\text { issle ilgili problemlerde elimde bulunan malzemeleri diğerleri ile } \\
\text { paylaşmaktan kaçınmam. }\end{array}$ & 4,46 & ,835 \\
\hline 5 & $\begin{array}{l}\text { is esnasında sorunla karşılaşan kişilere yardım etmek için gerekli } \\
\text { zamanı ayırırım. }\end{array}$ & 4,36 & ,839 \\
\hline 6 & Zamanımın çoğunu işimle ilgili faaliyetlerle geçiririm. & 3,89 & 1,062 \\
\hline 7 & Şirketim için olumlu imaj yaratacak tüm faaliyetlere katılmak isterim. & 4,29 & ,942 \\
\hline 8 & Mesai içerisinde kişisel işlerim için zaman harcamam. & 3,85 & 1,103 \\
\hline 9 & Diğer çalışanların hak ve hukukuna saygı gösteririm. & 4,62 & ,736 \\
\hline 10 & $\begin{array}{l}\text { Beklenmeyen problemler oluştuğunda diğer çalışanları zarar } \\
\text { görmemeleri için uyarırım. }\end{array}$ & 4,48 & 763 \\
\hline 11 & $\begin{array}{l}\text { Birlikte görev yaptığım diğer kişiler için problem yaratmamaya gayret } \\
\text { ederim. }\end{array}$ & 4,50 & ,796 \\
\hline 12 & Önemsiz sorunlar için şikayet ederek vaktimi boşa harcamam. & 4,38 & ,884 \\
\hline 13 & $\begin{array}{l}\text { Çalışma ortamı ile ilgili problemlere odaklanmak yerine olayların pozitif } \\
\text { yönünü görmeye çalışırım. }\end{array}$ & 4,22 & ,938 \\
\hline 14 & $\begin{array}{l}\text { Çalışma ortamında yaşadığım yeni durumlara karşı gücenme ya da } \\
\text { kızgınlık duymam. }\end{array}$ & 3,96 & 1,010 \\
\hline 15 & İşletme içerisinde çıkan çatışmaların çözümlenmesinde aktif rol alırım. & 3,93 & 1,029 \\
\hline 16 & $\begin{array}{l}\text { Üst yönetimce yayımlanan duyuru, mesaj, prosedür ya da kısa notları } \\
\text { okurum ve ulaşabileceğim bir yerde bulundururum. }\end{array}$ & 4,28 & ,867 \\
\hline 17 & işletmenin sosyal faaliyetlerine kendi isteğimle katııırım. & 4,16 & ,980 \\
\hline 18 & îşletme yapısında yapılan değişimlere ayak uydururum. & 4,30 & 867 \\
\hline 19 & $\begin{array}{l}\text { Her türlü geliştirici faaliyet icra eden araştırma ve proje gruplarının } \\
\text { içerisinde yer alırım. }\end{array}$ & 4,06 & 955, \\
\hline
\end{tabular}

\subsection{Araştırmada Kullanılan Ölçeklere İlişkin Faktör Analizi}

Araştırmanın bu bölümünde, psikolojik güçlendirme ve örgütsel vatandaşlık davranışı ölçeklerine ilişkin faktör analizi değerlerine yer verilmektedir. Katılımcılarla ilgili açıklayıcı istatistikleri belirledikten sonra çalışmada yapısal geçerliliği test etmek amacıyla faktör analizinden faydalanılmıştır; öncelikle boyutları elde etmek ve anketin 
geçerliliğini saptamak amacıyla ölçeklerde bulunan ifadeler açıklayıcı faktör analizine tabi tutulmuştur. Tablo 6 ve Tablo 7'de sunulduğu üzere, araştırmada kullanılan ölçeklerden psikolojik güçlendirme algısının dört(anlamlılık, yeterlilik, özerklik, etki); örgütsel vatandaşlık davranışı ölçeğinin ise beş(özgecilik, vicdanlılık, nezaket, centilmenlik, sivil erdem) alt boyuta ayrıldığı görülmektedir. Tablo 6 ve Tablo 7 incelendiğinde elde edilen faktör boyutlarının toplam varyansları $\% 70$ ve üzerinde olup bu değerler kabul edilebilir 3'te 2'lik varyans açıklama oranını sağlamaktadır (Nakip, 2003; Büyüköztürk, 2002).

\section{Tablo 6: Psikolojik Güçlendirme Ölçeği Faktör Analizi}

\begin{tabular}{|c|c|c|c|}
\hline Boyut & İfadeler & $\begin{array}{l}\text { Faktör } \\
\text { Yükü }\end{array}$ & $\begin{array}{l}\text { Açıklanan } \\
\text { Varyans }\end{array}$ \\
\hline \multirow{3}{*}{ Anlamlılık } & Yaptığım iş benim için önemlidir. & 0,885 & \multirow{3}{*}{22,138} \\
\hline & $\begin{array}{l}\text { İşimle ilgili yaptığım faaliyetler benim için özel bir } \\
\text { anlam taşır. }\end{array}$ & 0,904 & \\
\hline & Yaptığım iş benim için anlamlıdır. & 0,834 & \\
\hline \multirow[t]{3}{*}{ Yeterlilik } & $\begin{array}{l}\text { İşimi yapmak için gereken yeteneklere sahip } \\
\text { olduğuma eminim. }\end{array}$ & 0,844 & \multirow{3}{*}{20,926} \\
\hline & İşimi yapmak için gerekli kapasiteye sahibim. & 0,846 & \\
\hline & $\begin{array}{l}\text { Işim için gereken becerilere uzmanlık seviyesinde } \\
\text { sahibim. }\end{array}$ & 0,719 & \\
\hline \multirow{3}{*}{ Özerklik } & İşimi nasıl yapacağımı belirleme konusunda özgürüm. & 0,812 & \multirow{3}{*}{20,852} \\
\hline & $\begin{array}{l}\text { İşimi nası yürüteceğime dair kararları kendim } \\
\text { verebiliyorum. }\end{array}$ & 0,867 & \\
\hline & $\begin{array}{l}\text { İşimi yaparken farklı yöntemleri seçme konusunda } \\
\text { özgürüm. }\end{array}$ & 0,804 & \\
\hline \multirow[t]{3}{*}{ Etki } & $\begin{array}{l}\text { Departmanımda olanlar üzerinde büyük bir kontrole } \\
\text { sahibim. }\end{array}$ & 0,809 & \multirow{3}{*}{18,722} \\
\hline & Departmanımdaki faaliyetler üzerindeki etkim fazladır. & 0,842 & \\
\hline & $\begin{array}{l}\text { Departmanımda olanlar üzerinde önemli bir etkiye } \\
\text { sahibim. }\end{array}$ & 0,883 & \\
\hline $\begin{array}{l}\text { Toplam } \\
\text { Varyans }\end{array}$ & & & 82,638 \\
\hline
\end{tabular}

Tablo 7: Örgütsel Vatandaşlık Davranışı Ölçeği Faktör Analizi

\begin{tabular}{|c|c|c|c|}
\hline Boyut & İfadeler & $\begin{array}{l}\text { Faktör } \\
\text { Yükü }\end{array}$ & $\begin{array}{l}\text { Açıklanan } \\
\text { Varyans }\end{array}$ \\
\hline \multirow{5}{*}{ Özgecilik } & Günlük izin alan bir çalışanın o günkü işlerini ben yaparım. & 0,864 & \multirow{5}{*}{7,262} \\
\hline & $\begin{array}{l}\text { Aşırı iş yükü ile uğraşan bir çalışma arkadaşıma yardım } \\
\text { ederim. }\end{array}$ & 0,598 & \\
\hline & $\begin{array}{l}\text { Yeni işe başlayan birisinin işi öğrenmesine yardımcı } \\
\text { olurum. }\end{array}$ & 0,726 & \\
\hline & $\begin{array}{l}\text { İşle ilgili problemlerde elimde bulunan malzemeleri } \\
\text { diğerleri ile paylaşmaktan kaçınmam. }\end{array}$ & 0,726 & \\
\hline & $\begin{array}{l}\text { İş esnasında sorunla karşılaşan kişilere yardım etmek için } \\
\text { gerekli zamanı ayırıım. }\end{array}$ & 0,662 & \\
\hline \multirow{3}{*}{ Vicdanlılık } & Zamanımın çoğunu işimle ilgili faaliyetlerle geçiririm. & 0,745 & \multirow[b]{3}{*}{9,970} \\
\hline & $\begin{array}{l}\text { Şirketim için olumlu imaj yaratacak tüm faaliyetlere } \\
\text { katılmak isterim. }\end{array}$ & 0,484 & \\
\hline & Mesai içerisinde kişisel işlerim için zaman harcamam & 0,776 & \\
\hline \multirow{3}{*}{ Nezaket } & Diğer çalışanların hak ve hukukuna saygı gösteririm. & 0,744 & \multirow{3}{*}{24,863} \\
\hline & $\begin{array}{l}\text { Beklenmeyen problemler oluştuğunda diğer çalışanları } \\
\text { zarar görmemeleri için uyarırım. }\end{array}$ & 0,755 & \\
\hline & $\begin{array}{l}\begin{array}{l}\text { Birlikte görev yaptığım diğer kişiler için } \\
\text { yaratmamaya gayret ederim. }\end{array} \\
\text { yablem }\end{array}$ & 0,750 & \\
\hline
\end{tabular}


Tablo 7'nin Devamı

\begin{tabular}{|c|c|c|c|}
\hline \multirow{4}{*}{ Centilmenlik } & $\begin{array}{l}\text { Önemsiz sorunlar için şikayet ederek vaktimi boşa } \\
\text { harcamam. }\end{array}$ & 0,650 & \multirow{4}{*}{11,255} \\
\hline & $\begin{array}{l}\text { Çalışma ortamı ile ilgili problemlere odaklanmak yerine } \\
\text { olayların pozitif yönünü görmeye çalışırım. }\end{array}$ & 0,793 & \\
\hline & $\begin{array}{l}\text { Çalışma ortamında yaşadığım yeni durumlara karşı } \\
\text { gücenme ya da kızgınlık duymam. }\end{array}$ & 0,652 & \\
\hline & $\begin{array}{l}\text { İşletme içerisinde çıkan çatışmaların çözümlenmesinde } \\
\text { aktif rol alırım. }\end{array}$ & 0,746 & \\
\hline \multirow{4}{*}{ Sivil Erdem } & $\begin{array}{l}\text { Üst yönetimce yayımlanan duyuru, mesaj, prosedür ya da } \\
\text { kısa notları okurum ve ulaşabileceğim bir yerde } \\
\text { bulundururum. }\end{array}$ & 0,701 & \multirow{4}{*}{16,698} \\
\hline & İşletmenin sosyal faaliyetlerine kendi isteğimle katılırım. & 0,609 & \\
\hline & İşletme yapısında yapılan değişimlere ayak uydururum. & 0,589 & \\
\hline & $\begin{array}{l}\text { Her türlü geliştirici faaliyet icra eden araştırma ve proje } \\
\text { gruplarının içerisinde yer alırım. }\end{array}$ & 0,670 & \\
\hline $\begin{array}{l}\text { Toplam } \\
\text { Varyans }\end{array}$ & & & 70,048 \\
\hline
\end{tabular}

\subsection{Korelasyon Analizi}

Bu bölümde, araştırmada kullanılan değişkenlerin birbirleri arasındaki ilişkiyi belirlemek adına yapılan Pearson korelasyon analizi sonuçlarına yer verilmektedir. Tablo 8'de sunulduğu üzere araştırmada kullanılan değişkenlerin tüm alt boyutlarının birbirleri arasında pozitif yönde anlamlı ilişkileri olduğu tespit edilmiştir. Aynı zamanda en yüksek düzeyde anlamlı ilişkinin psikolojik güçlendirme algısı alt boyutlarından "anlamlılık" ve örgütsel vatandaşlık davranışı alt boyutlarından "özgecilik" arasında olduğu görülmektedir.

Tablo 8: Psikolojik Güçlendirme Algısı ile Örgütsel Vatandaşlık Davranışı Arasındaki İlişkiyi Belirlemeye Yönelik Pearson Korelasyon Analizi

\begin{tabular}{|c|c|c|c|c|c|c|}
\hline N=434 & & Özgecilik & Vicdanlılık & Nezaket & Centilmenlik & Sivil Erdem \\
\hline \multirow{2}{*}{ Anlamlılık } & $\mathrm{R}$ & $0,543^{*}$ & $0,349^{*}$ & $0,480^{*}$ & $0,440^{\star}$ & $0,530^{*}$ \\
\cline { 2 - 7 } & $\mathrm{P}$ & 0,000 & 0,000 & 0,000 & 0,000 & 0,000 \\
\hline \multirow{2}{*}{ Oeterlilik } & $\mathrm{R}$ & $0,440^{*}$ & $0,291^{*}$ & $0,441^{*}$ & $0,311^{*}$ & $0,431^{*}$ \\
\cline { 2 - 7 } & $\mathrm{P}$ & 0,000 & 0,000 & 0,000 & 0,000 & 0,000 \\
\hline \multirow{2}{*}{ Etzerklik } & $\mathrm{R}$ & $0,443^{*}$ & $0,333^{*}$ & $0,290^{*}$ & $0,401^{*}$ & $0,383^{*}$ \\
\cline { 2 - 7 } & $\mathrm{P}$ & 0,000 & 0,000 & 0,000 & 0,000 & 0,000 \\
\hline & $\mathrm{R}$ & $0,342^{*}$ & $0,300^{*}$ & $0,182^{*}$ & $0,295^{\star}$ & $0,323^{*}$ \\
\cline { 2 - 7 } & $\mathrm{P}$ & 0,000 & 0,000 & 0,000 & 0,000 & 0,000 \\
\hline
\end{tabular}

\subsection{Farklılıkları Belirlemeye Yönelik Analizler}

$\mathrm{Bu}$ bölümde, araştırmada kullanılan ölçekler ile demografik değişkenler arasında farklılıklar bulunup bulunmadığına ilişkin analizlere yer verilmektedir. Tablo 9'da listelendiği üzere psikolojik güçlendirme ve örgütsel vatandaşlık davranışı ölçekleri ile bireyin cinsiyeti arasında anlamlı bir farklılık olmadığı görülmektedir. 
Tablo 9: Araştırmada Kullanılan Ölçekler ile Bireyin Cinsiyeti Arasındaki Farklılığa İlişkin t-testi Analizi

\begin{tabular}{|c|c|c|c|c|c|c|}
\hline Değişkenler & Cinsiyet & $\mathbf{N}$ & Ort. & S.S. & $\mathbf{T}$ & $\mathbf{P}$ \\
\hline \multirow{2}{*}{ Anlamlılık } & Erkek & 253 & 4,28 & 0,82 & \multirow{2}{*}{1,435} & \multirow{2}{*}{0,152} \\
\hline & Kadın & 181 & 4,40 & 0,87 & & \\
\hline \multirow{2}{*}{ Yeterlilik } & Erkek & 253 & 4,32 & 0,68 & \multirow{2}{*}{1,339} & \multirow{2}{*}{0,181} \\
\hline & Kadın & 181 & 4,41 & 0,71 & & \\
\hline \multirow{2}{*}{ Özerklik } & Erkek & 253 & 3,64 & 0,96 & \multirow{2}{*}{1,620} & \multirow{2}{*}{0,106} \\
\hline & Kadın & 181 & 3,79 & 1,00 & & \\
\hline \multirow{2}{*}{ Etki } & Erkek & 253 & 3,56 & 1,07 & \multirow{2}{*}{0,386} & \multirow{2}{*}{0,700} \\
\hline & Kadın & 181 & 3,60 & 1,06 & & \\
\hline \multirow{2}{*}{ Özgecilik } & Erkek & 253 & 4,30 & 0,64 & \multirow{2}{*}{0,641} & \multirow{2}{*}{0,522} \\
\hline & Kadın & 181 & 4,26 & 0,74 & & \\
\hline \multirow{2}{*}{ Vicdanlılık } & Erkek & 253 & 3,96 & 0,78 & \multirow{2}{*}{1,119} & \multirow{2}{*}{0,264} \\
\hline & Kadın & 181 & 4,05 & 0,86 & & \\
\hline \multirow{2}{*}{ Nezaket } & Erkek & 253 & 4,51 & 0,61 & \multirow{2}{*}{0,573} & \multirow{2}{*}{0,567} \\
\hline & Kadın & 181 & 4,55 & 0,73 & & \\
\hline \multirow{2}{*}{ Centilmenlik } & Erkek & 253 & 4,10 & 0,74 & \multirow{2}{*}{0,726} & \multirow{2}{*}{0,469} \\
\hline & Kadın & 181 & 4,15 & 0,71 & & \\
\hline \multirow{2}{*}{ Sivil Erdem } & Erkek & 253 & 4,12 & 0,75 & \multirow{2}{*}{2,331} & \multirow{2}{*}{0,120} \\
\hline & Kadın & 181 & 4,29 & 0,74 & & \\
\hline
\end{tabular}

Tablo 10'da sunulduğu üzere, bireyin sahip olduğu medeni durum ile örgütsel vatandaşlık sergileme eğilimi arasında anlamlı bir farklılık olduğu görülmektedir.

Tablo 10: Araştırmada Kullanılan Ölçekler ile Bireyin Medeni Durumu Arasındaki Farklılığa İlişkin ANOVA Analizi

\begin{tabular}{|c|c|c|c|}
\hline Değişkenler & Df & $\mathbf{F}$ & Anlamlılık (p) \\
\hline Anlamlılık & 433 & 7,315 & $\mathbf{0 , 0 0 1}$ \\
\hline Yeterlilik & 433 & 0,218 & $\mathbf{0 , 8 0 5}$ \\
\hline Özerklik & 433 & 1,709 & $\mathbf{0 , 1 8 2}$ \\
\hline Etki & 433 & 1,748 & $\mathbf{0 , 1 7 5}$ \\
\hline Özgecilik & 433 & 12,374 & $\mathbf{0 , 0 0 0}$ \\
\hline Vicdanlılık & 433 & 4,842 & $\mathbf{0 , 0 0 8}$ \\
\hline Nezaket & 433 & 7,048 & $\mathbf{0 , 0 0 1}$ \\
\hline Centilmenlik & 433 & 9,397 & $\mathbf{0 , 0 0 0}$ \\
\hline Sivil Erdem & 433 & 8,659 & $\mathbf{0 , 0 0 0}$ \\
\hline
\end{tabular}

Tablo 11'de listelendiği üzere, bireyin yaşı ile psikolojik güçlendirilme algısı arasında anlamlı bir farklılık olduğu tespit edilmiştir.

Tablo 11: Araştırmada Kullanılan Ölçekler ile Bireyin Yaş Grubu Arasındaki Farklılığa İlişkin ANOVA Analizi

\begin{tabular}{|c|c|c|c|}
\hline Değişkenler & Df & F & Anlamlılık (p) \\
\hline Anlamlılık & 433 & 0,646 & $\mathbf{0 , 0 3 0}$ \\
\hline Yeterlilik & 433 & 4,672 & $\mathbf{0 , 0 0 1}$ \\
\hline Özerklik & 433 & 4,362 & $\mathbf{0 , 0 0 2}$ \\
\hline Etki & 433 & 6,255 & $\mathbf{0 , 0 0 0}$ \\
\hline Özgecilik & 433 & 3,113 & $\mathbf{0 , 0 7 5}$ \\
\hline Vicdanlılık & 433 & 2,288 & $\mathbf{0 , 0 5 9}$ \\
\hline Nezaket & 433 & 2,202 & $\mathbf{0 , 0 6 8}$ \\
\hline Centilmenlik & 433 & 2,063 & $\mathbf{0 , 0 8 5}$ \\
\hline Sivil Erdem & 433 & 1,325 & $\mathbf{0 , 2 6 0}$ \\
\hline
\end{tabular}


Bireyin konaklama işletmesinde çalıştığı bölüm ile psikolojik güçlendirme algısı ve örgütsel vatandaşlık sergileme eğilimi arasında anlamlı bir farklılığın olduğu Tablo 12 'de sunulmaktadır.

Tablo 12: Araştırmada Kullanılan Ölçekler ile Bireyin Çalıştığı Bölüm Arasındaki Farklılığa İlişkin ANOVA Analizi

\begin{tabular}{|c|c|c|c|}
\hline Değişkenler & Df & F & Anlamlılık (p) \\
\hline Anlamlılık & 433 & 4,555 & $\mathbf{0 , 0 0 0}$ \\
\hline Yeterlilik & 433 & 5,930 & $\mathbf{0 , 0 0 0}$ \\
\hline Özerklik & 433 & 2,495 & $\mathbf{0 , 0 0 6}$ \\
\hline Etki & 433 & 3,187 & $\mathbf{0 , 0 0 1}$ \\
\hline Özgecilik & 433 & 4,658 & $\mathbf{0 , 0 0 0}$ \\
\hline Vicdanlılık & 433 & 2,963 & $\mathbf{0 , 0 0 1}$ \\
\hline Nezaket & 433 & 4,298 & $\mathbf{0 , 0 0 0}$ \\
\hline Centilmenlik & 433 & 3,013 & $\mathbf{0 , 0 0 1}$ \\
\hline Sivil Erdem & 433 & 2,922 & $\mathbf{0 , 0 0 1}$ \\
\hline
\end{tabular}

Tablo 13'e bakıldığında, bireyin turizm sektöründeki çalışma tecrübesi ile psikolojik güçlendirilme algısı arasında anlamlı bir farklılık olduğu görülmektedir. Ek olarak bireyin turizm sektöründeki çalışma süresi ile örgütsel vatandaşlık algısı arasında anlamlı bir farklılık olmadığı görülmektedir.

Tablo 13: Araştırmada Kullanılan Ölçekler ile Bireyin Turizm Sektöründeki Çalışma Süresi Arasındaki Farklılığa İlişkin ANOVA Analizi

\begin{tabular}{|c|c|c|c|}
\hline Değişkenler & Df & F & Anlamlılık (p) \\
\hline Anlamlılık & 433 & 1,572 & $\mathbf{0 , 0 0 7}$ \\
\hline Yeterlilik & 433 & 3,818 & $\mathbf{0 , 0 0 2}$ \\
\hline Özerklik & 433 & 2,626 & $\mathbf{0 , 0 2 4}$ \\
\hline Etki & 433 & 5,933 & $\mathbf{0 , 0 0 0}$ \\
\hline Özgecilik & 433 & 2,175 & $\mathbf{0 , 0 5 6}$ \\
\hline Vicdanlılık & 433 & 1,834 & $\mathbf{0 , 1 0 5}$ \\
\hline Nezaket & 433 & 0,831 & $\mathbf{0 , 5 2 8}$ \\
\hline Centilmenlik & 433 & 2,065 & $\mathbf{0 , 0 6 9}$ \\
\hline Sivil Erdem & 433 & 1,500 & $\mathbf{0 , 1 8 9}$ \\
\hline
\end{tabular}

Bireyin bulunduğu işletmedeki çalışma tecrübesi ile psikolojik güçlendirilme algısı arasındaki farklılık durumunu gösteren analiz Tablo 14'te verilmektedir. Bireyin bulunduğu işletmedeki çalışma tecrübesi ile psikolojik güçlendirilme algısı arasında "Anlamlılık" boyutu haricinde anlamlı bir farklılık olduğu görülmekle birlikte örgütsel vatandaşlık algısı ile arasında anlamlı bir farklılık olmadığı görülmektedir.

Tablo 14: Araştırmada Kullanılan Ölçekler ile Bireyin Bulunduğu İşletmedeki Çalışma Süresi Arasındaki Farklılığa İlişkin ANOVA Analizi

\begin{tabular}{|c|c|c|c|}
\hline Değişkenler & Df & F & Anlamlıık (p) \\
\hline Anlamlılık & 433 & 0,541 & $\mathbf{0 , 7 4 5}$ \\
\hline Yeterlilik & 433 & 2,590 & $\mathbf{0 , 0 2 5}$ \\
\hline Özerklik & 433 & 3,249 & $\mathbf{0 , 0 0 7}$ \\
\hline Etki & 433 & 5,114 & $\mathbf{0 , 0 0 0}$ \\
\hline Özgecilik & 433 & 1,053 & $\mathbf{0 , 3 8 6}$ \\
\hline Vicdanlılık & 433 & 1,027 & $\mathbf{0 , 4 0 1}$ \\
\hline Nezaket & 433 & 0,398 & $\mathbf{0 , 8 5 0}$ \\
\hline Centilmenlik & 433 & 0,777 & $\mathbf{0 , 5 6 7}$ \\
\hline Sivil Erdem & 433 & 0,709 & $\mathbf{0 , 6 1 7}$ \\
\hline
\end{tabular}


Tablo 15’te sunulduğu üzere, bireyin sahip olduğu eğitim durumu ile örgütsel vatandaşlık davranışı sergileme eğilimi arasında anlamlı bir farklılık olduğu görülmektedir. Buna ek olarak bireyin eğitim seviyesi ile psikolojik güçlendirme algısı arasında anlamlı bir farklılık olmadığı tespit edilmiştir.

Tablo 15: Araştırmada Kullanılan Ölçekler ile Bireyin Eğitim Seviyesi Arasındaki Farklılığa İlişkin ANOVA Analizi

\begin{tabular}{|c|c|c|c|}
\hline Değişkenler & Df & $\mathbf{F}$ & Anlamlılık (p) \\
\hline Anlamlılık & 433 & 2,221 & $\mathbf{0 , 0 5 1}$ \\
\hline Yeterlilik & 433 & 2,538 & $\mathbf{0 , 0 5 8}$ \\
\hline Özerklik & 433 & 1,579 & $\mathbf{0 , 1 6 5}$ \\
\hline Etki & 433 & 1,385 & $\mathbf{0 , 2 2 9}$ \\
\hline Özgecilik & 433 & 1,952 & $\mathbf{0 , 0 3 5}$ \\
\hline Vicdanlılık & 433 & 3,527 & $\mathbf{0 , 0 0 4}$ \\
\hline Nezaket & 433 & 3,139 & $\mathbf{0 , 0 0 9}$ \\
\hline Centilmenlik & 433 & 3,267 & $\mathbf{0 , 0 0 7}$ \\
\hline Sivil Erdem & 433 & 2,296 & $\mathbf{0 , 0 4 5}$ \\
\hline
\end{tabular}

\section{Tartişma ve Sonuç}

Alan yazında yer alan çalışmalara bakıldığında, Yücel ve Demirel (2012)'in kamu kuruluşunda yapmış oldukları bir araştırmada personel güçlendirmenin örgütsel vatandaşlık davranışı sergileme eğilimini olumlu bir şekilde etkilediği sonucuna varmışlardır. İlisu (2012)'nun sağlık sektörü üzerinde yapmış olduğu araştırmada da, örgüt içerisinde personel güçlendirmenin etkin bir şekilde uygulanması, personelin örgütsel vatandaşlık davranışı sergilemesine katkı sağlayacağı ve işten ayrılma niyeti düzeyini düşüreceği sonucuna varmıştır. Yürür ve Demir'in (2011) psikolojik güçlendirme ile örgütsel adalet arasındaki ilişkiyi incelemek adına ortaya koydukları araştırmada, personelin kendisini güçlendirilmiş hissetmesinin örgütsel adalet algısını arttırdığını, aynı zamanda personelin adalet algılamalarının, personelin kendisini güçlendirilmiş hissetmesine katkı sağladığını tespit etmişlerdir. Atalay (2010)'ın İstanbul'da ilaç sektörü grubuna yönelik yapmış olduğu araştırmada, personel güçlendirme algısı ile örgütsel vatandaşlık davranışı arasında güçlü ve anlamlı bir ilişkinin varlığının olduğu ortaya çıkmıştır. Çöl'ün (2008) personelin kendisini güçlendirilmiş hissetme algısının performansına etkisini ölçmek üzere yapmış olduğu çalışmada, personelin işini anlamlı ve kendini işi konusunda yeterli görme algısının performansını arttırıcı yönde etki ettiğini ortaya koymaktadır. Çekmecelioğlu ve Eren (2007) psikolojik güçlendirmenin, örgütsel bağlılık ve yaratıcı davranışlar arasındaki ilişkiyi inceledikleri araştırmada, psikolojik güçlendirmenin hem yaratıcı davranışları hem de örgütsel bağlılığı pozitif yönde etkilediğini tespit etmişlerdir.

Yapılan bu araştırmada elde edilen analiz sonuçlarında da, personel güçlendirmenin örgütsel vatandaşlık davranışı sergileme eğilimini olumlu yönde etkilemekte olduğu sonucuna varılmıştır. Bu doğrultuda, bu araştırma, psikolojik güçlendirmenin örgütsel vatandaşlık davranışı sergilenmesi eğilimini olumlu yönde etkilediğini ifade eden bir yaklaşımla mevcut yazına katkı sağlamaktadır. Araştırmada elde edilen bulguların ışığında konu değerlendirildiğinde, araştırmaya katılan bireylerin kendilerini, yaptıkları iş için yeterli gördükleri, ilgili frekans analizleri aracılığıyla ortaya konmaktadır. Bu durum işletmelerin personeline uyguladığı eğitim ve oryantasyon uygulamalarının ne derecede önemli olduğunu göstermektedir. İş öncesi ya da süresince personeline gerekli eğitimlerin işletme tarafından verilmesi, personelin kendisini güçlü hissetmesine neden olacak kıstasların başında gelmektedir. Aynı zamanda araştırmaya katılan bireylerin örgütsel vatandaşlık sergileme eğilimi ile ilgili frekans analizlerine bakıldığında nezaket boyutunun ön plana çıktığı görülmektedir. Bu 
durum araştırmaya katılan bireylerin diğer çalışma arkadaşlarına ve onların haklarına karşı ne kadar saygılı olduğunun bir göstergesini oluşturmaktadır.

Araştırma ile ilgili korelasyon analizi sonuçları ise psikolojik güçlendirme alt boyutlarından anlamlılık ile örgütsel vatandaşlık davranışı alt boyutlarından özgecilik arasında güçlü ve anlamlı bir ilişki bulunduğunu göstermektedir. Bu doğrultuda işletmeler, personelinin işini anlamlı görebilmesi için personeline yetki devri verebilmesi, kararlara katılımını sağlaması ve onları işine karşı motive edebilmesi gibi yönetimsel uygulamalara ağırlık vermesini gerektirdiğini göstermektedir. Böylece personel işletme içerisinde diğer çalışma arkadaşlarına karşı daha yardımsever bir tutumla hareket edecek ve işletme hedeflerinin gerçekleşmesine bireysel olarak katkı sağlayacaktır.

Araştırmada kullanılan ölçeklerin demografik özellikler ile ilgili farklılıklarını tespit etmeye yönelik yapılan testler ve tamamlayıcı istatiksel analizler sonucunda, araştırmaya katılan bireylerin medeni durumunun örgütsel vatandaşlık davranışı sergileme eğilimine göre anlamlı derecede farklılıklar gösterdiği tespit edilmiştir. Medeni durumu "evli" olan bireylerin "bekâr" olanlara göre daha fazla örgütsel vatandaşlık davranışı gösterdiği tespit edilmiştir. Evli çalışanların aile ile ilgili sorumluluklarının diğerlerine oranla daha fazla olması ve kendi yönetimlerinde bir aile kurumunun içerisinde olmaları bağlılık ve ait olma davranışlarını güçlendirir etki yapabilmektedir. Yaş grubu 18-24 ve 25- 44 olan bireylerin psikolojik olarak güçlendirilmiş hissetme algısının diğer yaş gruplarına göre daha yüksek olduğu tespit edilmiştir. Bu durum bu yaş grubundaki bireylerin güçlendirilmeye daha eğilimli olduğunun göstergesi olarak görülmektedir. Bunun yanı sıra turizm sektöründeki tecrübesi 1-5 ve 6-10 yıl arasında olan bireylerin güçlendirilme eğilimlerinin daha uzun süre işletmede görev yapmış kişilere oranla daha yüksek olduğu ortaya konmaktadır. Araştırmanın bu sonucu, işletme içerisinde görev yapan personelin ilk 10 yıl içerisinde işini daha anlamlı, zamanla kendini daha yeterli, inisiyatif kullanabilen ve departmanına etki edebilen bir birey olduğunu göstermektedir. Araştırmadan çıkan diğer bir anlamlı farklılık sonucu ise eğitim durumu lisans ve yüksek lisans olan personelin, diğer eğitim durumlu personele oranla daha fazla örgütsel vatandaşlık davranış sergileme eğiliminin olmasıdır. Belli bir eğitim düzeyine gelmiş personel, çalışma ortamında daha bilinçli, istekli ve hedefli bir şekilde hareket etmektedir.

Psikolojik güçlendirme sürecinin konaklama işletmelerinde uygulanmasında bazı sorunlar söz konusu olmaktadır. Bu sorunların en başında; yöneticilerin, kontrolünü ya da gücünü kaybedeceğini düşünerek personeli psikolojik olarak güçlendirme adına yeterli desteği vermemesi gelmektedir. Bunun yanı sıra personele, karar verme, sorumluluk alma ve faaliyetleri yerine getirme hususunda güvenilmemesi ve bu doğrultuda uygun bir eğitim ortamının oluşturulmaması da güçlendirilmiş personel oluşturmada oldukça önemli bir engel teşkil etmektedir. Aynı zamanda konaklama işletmesi içerisinde etkin bir performans değerlendirme sisteminin olmaması, personelin bilgilere ve kaynaklara ulaşımının desteklenmemesi gibi durumlar da psikolojik güçlendirme sürecini olumsuz etkileyen unsurlar olarak görülmektedir.

Müşteri ile birebir iletişimin sıklıkla gerçekleşmesi ve müşteri memnuniyetinin sağlanması için müşteri istek, şikâyet ya da ihtiyaçlarına hızlı bir biçimde cevap verebilme zorunluluğu gibi özellikleri olan konaklama işletmelerinde de güçlendirilmiş personelin olması çok büyük önem arz etmektedir. Kendisini güçlendirilmiş hisseden personel, yaptığı işe hâkim, kendine güveni yüksek ve çözüm odaklı bir bakış açısına sahip olacaktır. Böylece etkin, hızlı ve verimli bir şekilde müşteri memnuniyetini sağlayabilecek girişimlerde bulunabilecektir. Konaklama işletmesinde görev yapan 
personelin, yaptığı işi anlamlı ve önemli görmesi, kendisinin o işi yapabilecek seviyede gereken yetenek ve yeterliliğe sahip olduğunu bilmesi, faaliyetlerini yerine getirirken inisiyatif kullanarak özgür bir şekilde karar verebilmesi, öz kontrolünü sağlayabilmesi ve işletmede ya da çalıştığı bölümde etki uyandırabileceğine olan inancı örgütsel vatandaşlık davranışı sergilemesine katkı sağlamaktadır.

Konaklama işletmelerinde görev yapan bölüm yöneticileri personeline yetki devri vererek, yönetime ve kararlara katılımını sağlayarak, onların motivasyonunu üst düzeyde tutarak, örgüt içerisinde açık bir iletişim ortamı oluşturarak, personelini eğiterek, gelişimlerini teşvik ederek, örgüt içerisinde güven ortamı oluşturarak personelini güçlendirilmiş hissettirebilir. Bunlara ek olarak, personelini ortak hedeflere yönelterek, örgüt içerisinde bilgi paylaşımını destekleyerek, personelin örgüt içerisinde kaynaklara ulaşabilmesini destekleyerek ve personeline yaptıkları faaliyetler ile ilgili geri bildirimler yaparak ve sorumluluklar vererek personelinin kendisini psikolojik olarak güçlendirilmiş hissetmesine katkı sağlayabilirler.

$\mathrm{Bu}$ noktada özellikle insan kaynakları yönetiminin politikaları hayati önem taşımaktadır. İnsan kaynakları yönetiminin, personele yapılan yatırımın bir gider olarak değil, geleceğe yapılmış olan bir yatırım olarak görmesi gerekmektedir. Bu doğrultuda, insan kaynakları yönetimi personelinin kendisini işi konusunda geliştirmesine imkan tanıyacak eğitim programları düzenlemesi gerekmektedir. İnsan kaynaklarının bu tarz bir bakış açısı benimsemesi personel devir hızının azalmasına da katkı sağlayacaktır.

Araştırma sonuçlarının Eylül - Aralık 2015 tarihlerinde İzmir il merkezinde yer alan beş yıldızlı konaklama işletmelerinde görev yapan personelin görüşleriyle sınırı olması, araştırmanın en önemli kısıtını oluşturmaktadır. Zaman ve maliyet kısıtından dolayı araştırmanın kapsamı sadece İzmir il merkezinde yer alan beş yıldızlı konaklama işletmeleri ile sınırlı tutulmaktadır. Bu durum araştırma sonuçlarının Türkiye genelindeki tüm konaklama işletmelerine uyarlanmasında engel oluşturmaktadır. İlerleyen çalışmalar için, psikolojik güçlendirmenin örgütsel vatandaşlık davranışına etkisi, turizm sektörünün diğer kolları (seyahat acenteleri, yiyecek-içecek işletmeleri, turizm rehberleri vb.) üzerinde de incelenebilir.

\section{Kaynakça}

Arı, G.S. (2014), 'Örgütlerde Fiziksel Semboller ve Psikolojik Güçlendirme İlişkisi Üzerine Kavramsal Bir Çalışma', H.Ü. İktisadi ve Ídari Bilimler Fakültesi Dergisi, 32(2), ss. 1-25.

Arslantaş C.C., (2007), 'Güçlendirici Lider Davranışının Psikolojik Güçlendirme Üzerindeki Etkisini Belirlemeye Yönelik Görgül Bir Araştırma', Anadolu Üniversitesi Sosyal Bilimler Dergisi, Vol.7, s. 227-240.

Aslan, Ş. (2008), 'Örgütsel Vatandaşlık Davranışı ile Örgütsel Bağlılık ve Mesleğe Bağlılık Arasındaki İlişkilerin Araştırılması', Yönetim ve Ekonomi Dergisi, 15(2), ss. 163-178.

Aslan, Ş. (2009), 'Karizmatik Liderlik ve Örgütsel Vatandaşlık Davranışı İlişkisi: Kurumda Çalışma Yılı ve Ücreti Değişikliklerinin Rolü' Uluslararası İnsan Bilimleri Dergisi, 6(1), ss. 256-275.

ATALAY, C. G. (2010), Personel Güçlendirme ve Örgütsel Vatandaşlık Davranışı Bağlamında İnsan Kaynakları Yönetimi. Ankara: Detay Yayıncılık.

Basım, Nejat H. ve Şeşen, Harun. (2006). Örgütsel Vatandaşlık Davranışı Ölçeği Uyarlama ve Karşılaştırma Çalışması. Ankara Üniversitesi SBF Dergisi. 61(4): 83-101. 
Büyüköztürk, Ş. (2002), Sosyal Bilimler için Veri Analizi El Kitabı, Pegem Yayıncılık, 2. Baskı, Ankara.

Çalışkan, A. ve Hazır, K. (2012), 'Psikolojik Güçlendirmenin İş Tatminine Etkisinde Örgütsel Bağlıı̆ı̆ın Aracılık Rolü', Cag University Journal of Social Sciences, 9(2), ss. 48-76.

Çavuş, D. M. F. (2008). Personel Güçlendirme: İmalat Sanayii İşletmelerinde Bir Araştırma. Journal of Yaşar University, 3(10), 1287-1300.

Çavuş, M. F., \& Akgemci, T. (2008). İşletmelerde Personel Güçlendirmenin Örgütsel Yaratıcılık Ve Yenilikçiliğe Etkisi: İmalat Sanayiinde Bir Araştırma. Selçuk Üniversitesi Sosyal Bilimler Enstitüsü Dergisi, (20), 229-244.

Çekmecelioğlu, H. G. ve Eren, E. (2007), 'Psikolojik Güçlendirme, Örgütsel Bağlılık ve Yaratıcı Davranış Arasındaki İlişkilerin Değerlendirilmesi', Yönetim, 18(57), ss. 13-25.

Çekmecelioğlu, H. G., \& Keleş, Ö. (2008). Örgüt İklimi, Güçlendirme ve Bireysel İş Performansı Arasındaki İlişkilerin Değerlendirilmesi. Muhan Soysal İşletmecilik Konferansı, 3-6.

Çelik, M. (2007), Örgüt Kültürü ve Örgütsel Vatandaşlık Davranışı Bir Uygulama, Yayınlanmamış Doktor Tezi, Atatürk Üniversitesi, Sosyal Bilimler Enstitüsü, Erzurum.

Çöl, G. (2008), 'Algılanan Güçlendirmenin İşgören Performansı Üzerine Etkileri', Doğuş Üniversitesi Dergisi, 9(1), ss. 35-46.

Demir, C. (2004a), 'The Importance of Human Resource Planning for Tourism Administration', Tourism, 52(3), ss. 293-298.

Demir, C. (2004b), 'A profile of Turkish tourism', International Journal of Contemporary Hospitality Management, 16(5), ss. 325 - 328.

Giderler, C. (2015), 'Sosyal Hizmet İşletmelerinde Personel Güçlendirme', Süleyman Demirel Üniversitesi Vizyoner Dergisi, Sosyal Hizmet Özel Sayısı, ss. 58-88.

Gürbüz, S. ve Yüksel, M. (2008), 'Çalışma Ortamında Duygusal Zeka: İş Performansı, İş Tatmini, Örgütsel Vatandaşlık Davranışı ve Bazı Demografik Özeliklerle İlişkisi', Doğuş Üniversitesi Dergisi, 9(2), ss. 174-190.

Halis, M. (2009), 'Temel İşletmecilik Kavramları ve Turizm' İçinde Demirkol, Ş. ve Zengin, B.(Editörler), Turizm İşletmeleri, ss. 41-64, İstanbul: Değişim Yayınları.

Işın, A.F. (2009) "Psikolojik Personel Güçlendirme ve İş Tatmini Arasındaki Ilişki ve Bir Uygulama" Yayınlanmamış Yüksek Lisans Tezi, İstanbul, İstanbul Üniversitesi Sosyal Bilimler Enstitüsü.

İlısu, İ. (2012). Personel Güçlendirmenin Örgütsel Vatandaşlık Davranışı ve İşten Ayrılma Niyetine Etkisi Üzerine Bir Araştırma, Niğde Üniversitesi SBE, İşletme ABD, Yönetim ve Organizasyon BD, Yüksek Lisans Tezi, Niğde.

Kalaycı, Ş. (2006), Çok Değişkenli İstatistik Teknikleri, Ankara: Asil Yayın Dağıtım.

Keleş, Y. ve Pelit, E. (2009), 'Otel İşletmesi İşgörenlerinin Örgütsel Vatandaşlık Davranışları: İstanbul'daki Beş Yıldızlı Otel İşletmelerinde Bir Araştırma', Ekonomik ve Sosyal Araştırmalar Dergisi, 5(2), ss. 24-45.

Lee, M. ve Koh J. (2001), 'Is Empowerment Really a New Concept', International Journal of Human Resources Management, 12(4), ss. 684-695.

Meydan, C.H., Şeşen, H. ve Basım, N.H. (2011), 'Adalet Algısı ve Tükenmişliğin Örgütsel Vatandaşlık Davranışları Üzerindeki Öncüllük Rolü', İş, Güç Endüstri iliş̧kileri ve İnsan Kaynakları Dergisi, 13(2), ss. 41-62.

Nakip, M. (2003), Pazarlama Araştırmaları: Teknikler ve Uygulamalar, Seçkin Kitabevi, Ankara.

Organ, D. W. (1988), Organizational Citizenship Behavior: The Good Soldier Syndrome, Lexington Books. England: 
Sökmen, A. ve Boylu, Y. (2011), 'Örgütsel Vatandaşlık Davranışı Cinsiyete Göre Farklılık Gösterir mi? Otel İşletmeleri Açısından Bir Değerlendirme', Gaziantep Üniversitesi Sosyal Bilimler Dergisi, 10(1), ss. 147-163.

Spreitzer, G. M. (1995), 'Psychological Empowerment in the Work Place: Dimensions, Measurement and Validation', Academy of Management, 38(5), ss. 1442-1465.

Spreitzer, G. M., De Janasz, S. C. ve Quinn, R. E. (1999), 'Empowered to lead: The Role of Psychological Empowerment in Leadership', Journal of Organizational Behaviour, 20(1), ss. 511-526.

Spreitzer, G. M., Kizilos, M. A. ve Nason, S. W. (1997), 'A Dimensional Analysis of the Relationship Between Psychological Empowerment and Effectiveness, Satisfaction and Strain', Journal of Management, 23(5), ss. 679-704.

Sürgevil, O., Tolay, E. ve Topoyan, M. (2013), 'Yapısal Güçlendirme ve Psikolojik Güçlendirme Ölçeklerinin Geçerlilik ve Güvenilirlik Analizleri', Journal of Yasar University, 8(31), ss. 5371-5391

Thomas, K. W. ve Velthouse, B. A. (1990), 'Cognitive Elements of Empowerment: An "Intrepretive" Model of Intrinsic Task Motivation', Academy of Management Review, 15(4), ss. 666-681.

Tolay, E., Sürgevil, O. ve Topoyan, M. (2012), 'Akademik Çalışma Ortamında Yapısal ve Psikolojik Güçlendirmenin Duygusal Bağlılık ve Îş Doyumu Üzerindeki Etkileri', Ege Akademik Bakış, 12(4), ss. 449- 465.

Turnipseed, D. L. (2002), 'Are Good Soldiers Good? Exploring The Link Between Organization Citizenship Behavior and Personal Ethics', Journal of Business Research. 55(1), ss. 1-15.

Vey, M. A. ve Campbell, J. P. (2004), "In.Role or Extra.Role Organization al Citizenship Behavior:Which Are We Measuring?", Human Performance, 17(1), pp.119-135.

Willıams, S. ve Shiaw, W. T. (1999), "Mood and Organizational Citizenship Behavior: The Effects of Positive Affect on Employee OCB Intentions", The Journal of Psychology, 133(6), pp.656-668.

Yeşilyurt, H. ve Koçak, N. (2014), 'İş Doyumu ve Örgütsel Vatandaşlık Davranışı Arasındaki İlişkinin Otel İşletmeleri Açısından İncelenmesi', Dokuz Eylül Üniversitesi Sosyal Bilimler Enstitüsü Dergisi, 16(2), ss. 303-324.

Yücel, İ. ve Demirel, Y. (2012), 'Psikolojik Güçlendirmenin Örgütsel Vatandaşlık Davranışına Etkisi Üzerine Bir Araştırma', Kocaeli Üniversitesi Sosyal Bilimler Enstitüsü Dergisi, 23(1), ss. 19-48.

Yürür, S. ve Demir, K. (2011), 'Örgütsel Adalet ve Psikolojik Güçlendirme: Karşılıklı Etkileri Üzerine Bir Araştırma', Süleyman Demirel Üniversitesi Iktisadi ve Idari Bilimler Fakültesi Dergisi, 16(3), ss. 311-335. 